\title{
Phosphorus concentrations into a subtropical lake strongly influence nitrogen accumulation, nitrogen export, and Chl $a$ concentrations
}

\author{
R. Eugene Turner (D) James M. Lee - Charles S. Milan • Erick M. Swenson
}

Received: 13 March 2021 / Revised: 17 July 2021 / Accepted: 20 July 2021 / Published online: 5 August 2021

(C) The Author(s) 2021

\begin{abstract}
We measured water quality monthly for 22 years in water entering, within, and exiting a 65 $\mathrm{km}^{2}$ shallow polymictic and eutrophic freshwater lake in the northern Gulf of Mexico. Fertilizer use in the watershed is the dominate source of phosphorous (P) going into the lake and controls the lake's $\mathrm{P}$ concentrations, but nitrogen $(\mathrm{N})$ fertilizer use was not related to total nitrogen concentration in the lake. Half of the particulate $\mathrm{P}$ entering the lake is trapped within it and there is a net accumulation of $\mathrm{N}$ that appears to be from the stimulation of nitrogen fixation. The lake's concentration of Chlorophyll a ( $\left.\mu \mathrm{g} \mathrm{Chl} a 1^{-1}\right)$ and increase in $\mathrm{N}$ in the lake was directly related to the concentration of $\mathrm{P}$ in water entering the lake. Variations in the Chl $a$ concentration within a freshwater lake downstream are also directly related to the annual use of $\mathrm{P}$ fertilizer, but not to $\mathrm{N}$ fertilizer use. Reducing agriculture-sourced $\mathrm{P}$ runoff will lower (but not eliminate) both the frequency of algal blooms within
\end{abstract}

Handling editor: Judit Padisák

Supplementary Information The online version contains supplementary material available at https://doi.org/10.1007/ s10750-021-04673-z.

R. E. Turner $(\bowtie) \cdot$ J. M. Lee · C. S. Milan .

E. M. Swenson

Department of Oceanography and Coastal Sciences,

Louisiana State University, Baton Rouge,

LA 70803, USA

e-mail: euturne@1su.edu
Lac des Allemands and the amount of $\mathrm{N}$ delivered to the estuary.

Keywords Eutrophication - Algal blooms · Landuse $\cdot$ Nitrogen $\cdot$ Phosphorus · Restoration

\section{Introduction}

The size, frequency, and toxicity of algal blooms in lakes have increased throughout the world as nutrient loading has risen over the last 200 years (Smith, 2003; Paerl \& Huisman, 2008; Michalak et al., 2013; Taranu et al., 2015; Harke et al., 2016; Paerl et al., 2016). The effects of this nutrient enrichment are modified by many factors including climate change, land use, lake morphometry, food webs, and hydrologic conditions (Downing et al., 2001; Sterner, 2008; Lewis \& Wurtsbaugh, 2008; Schindler, 2012; Bertani et al., 2017). The diversity of outcomes requires site-specific assessments that bring a thorough understanding of the ecosystem.

A persistent point of focus and recent dispute is how, why, or which nutrients are primary, secondary, or co-limiting influences and in what ratios (Conley et al., 2009; Schindler, 2012; Paerl et al., 2016; Schindler et al., 2016, Wurtsbaugh et al., 2019). How to advance water quality improvements is an important management issue. Schindler (2012) points out, 
for example, that the cost of reducing only $\mathrm{P}$ loading to control algal biomass would be $10 \%$ of a $\mathrm{N}+\mathrm{P}$ management program in the Baltic Sea and 20\% for the City of Winnipeg, Ontario, Canada, whereas others suggest that efforts may be unsuccessful if $\mathrm{N}$ loading is not reduced concurrently (Paerl et al., 2016). The annual economic losses from eutrophication for recreation, real estate, species conservation, and drinking water in the USA exceeded $\$ 2.2$ billion annually (Dodds et al., 2009) and half of the US stream and river miles violate water pollution standards (Keiser \& Shapiro, 2017). There are links between nitrate in drinking water and birth defects (neural tube and spinal cord including spina bifida, oral cleft defects, and limb deficiencies; Brender et al., 2013) and bladder and thyroid cancer (Ward et al., 2018). So, there is a strictly scientific understanding being developed that has consequences for water quality restoration, cost, health, and society well-being. How do we advance understanding in order to address concerns about water quality?

Reviews emphasize the usefulness of long-term, whole-lake experiments or case studies lasting longer than a decade (e.g., Jeppesen et al., 2005; Lewis \& Wurtsbaugh, 2008; Sterner, 2008; Schindler, 2012). Large-scaled analyses potentially have several advantages (sensu; Lewis \& Wurtsbaugh, 2008; Schindler, 2012): (1) they avoid potential artifacts produced in bottle-sized or mesocosm-scaled studies of much shorter duration and that exclude the entirety of a lake's food webs; (2) observations about the natural variability of lakes and incoming waters can give clues about how to reverse eutrophication that can be more insightful than adding nutrients in a narrowly prescribed format; (3) a lake ecosystem has properties (behaviors) that transcend individual components. Different components in a lake, for example, change heterogeneously: sediments release $\mathrm{P}$ at different rates during the year and among years; flushing rates may be asynchronous with temperature cycles. The smallerscaled studies can focus on meaningful pieces of the puzzle, whereas lake-sized studies integrate responses as a whole in a way that studies of sub-sections cannot.

Implicit in these arguments for whole-lake analyses then is that a lake reflects the watershed, and so nutrient loading must be considered an essential part of understanding lake ecology. Hutchinson (1936) put it this way: "Each shade of blue or green sums up in itself a structure and a history, for each lake is a small world, making its nature known to the larger world of the desert most clearly in its colour. These little worlds of turquoise, set among red, brown, grey and white rocks, are not independent of the dry landscape around them. In the quality of this scene, accentuated by the foetid sulphurous water that lies at the bottom of the lake, may be traced the whole life of the surrounding country." The variations in water quality and amounts going into lakes, in other words, inform what happens within the lake and vice versa. Further, using only a few years of data may not disclose lagged and nonlinear responses in a $\mathrm{P}$ limited system (e.g., Chorus et al., 2020) that is the result of a nuanced interplay of nutrient limitations on cellular uptake and division, cellular storage (quotas), and total potential accumulation (Chorus and Köhler 2021).

We followed the advice given above to measure various water quality indices in water going into, within, and exiting a shallow lake for each month over 22 years. The lake is embedded within a southern Louisiana, USA, agricultural landscape whose area is part of the $99.9 \%$ of lakes in the world that are smaller than $100 \mathrm{~km}^{2}$ (Downing et al., 2006). The concentration of $\mathrm{N}$ and $\mathrm{P}$ changed from month to month, and year to year, and so we could follow the rise and fall of nutrient concentration enrichment and retraction and their relationships to algal biomass accumulation. The focus was to determine how algal biomass in the lake changed as inorganic and organic forms of nitrogen and phosphorus entering the lake fluctuated, how much nitrogen accumulated, and how land use affected water quality. We also examined the relationship between fertilizer use and Chl $a$ in a freshwater coastal lake downstream. The fundamental significance of $\mathrm{P}$ loading on the lake's $\mathrm{N}$ and algal biomass accumulation and subsequent export may be more broadly applicable to these now common agricultural landscapes.

\section{Methods}

Site description

Lac des Allemands $\left(29.915^{\circ} \mathrm{N}, 90.573^{\circ} \mathrm{W}\right)$ is a $65 \mathrm{~km}^{2}$ lake in the freshwater end of the $6,600 \mathrm{~km}^{2}$ Barataria watershed located west of the Mississippi River in southeastern Louisiana, USA (Fig. 1). Its watershed is $16 \%\left(998 \mathrm{~km}^{2}\right)$ of the total Barataria 
Fig. 1 The location of Lac des Allemands and Little Lake in southern Louisiana. Bayou Chevreuil enters Lac des Allemands which drains into Lake Salvador and then into Little Lake, and then into Barataria Bay which mixes with the Gulf of Mexico. Three sub-sections of the Lac des Allemands watershed are outlined in red and the area of forest swamp, agriculture, and urban/industry is in the bar graph. The inset in the lower left corner shows stations in red in Bayou Chevreuil, black dots are stations in the lake, and green dots are stations in water after exiting the lake

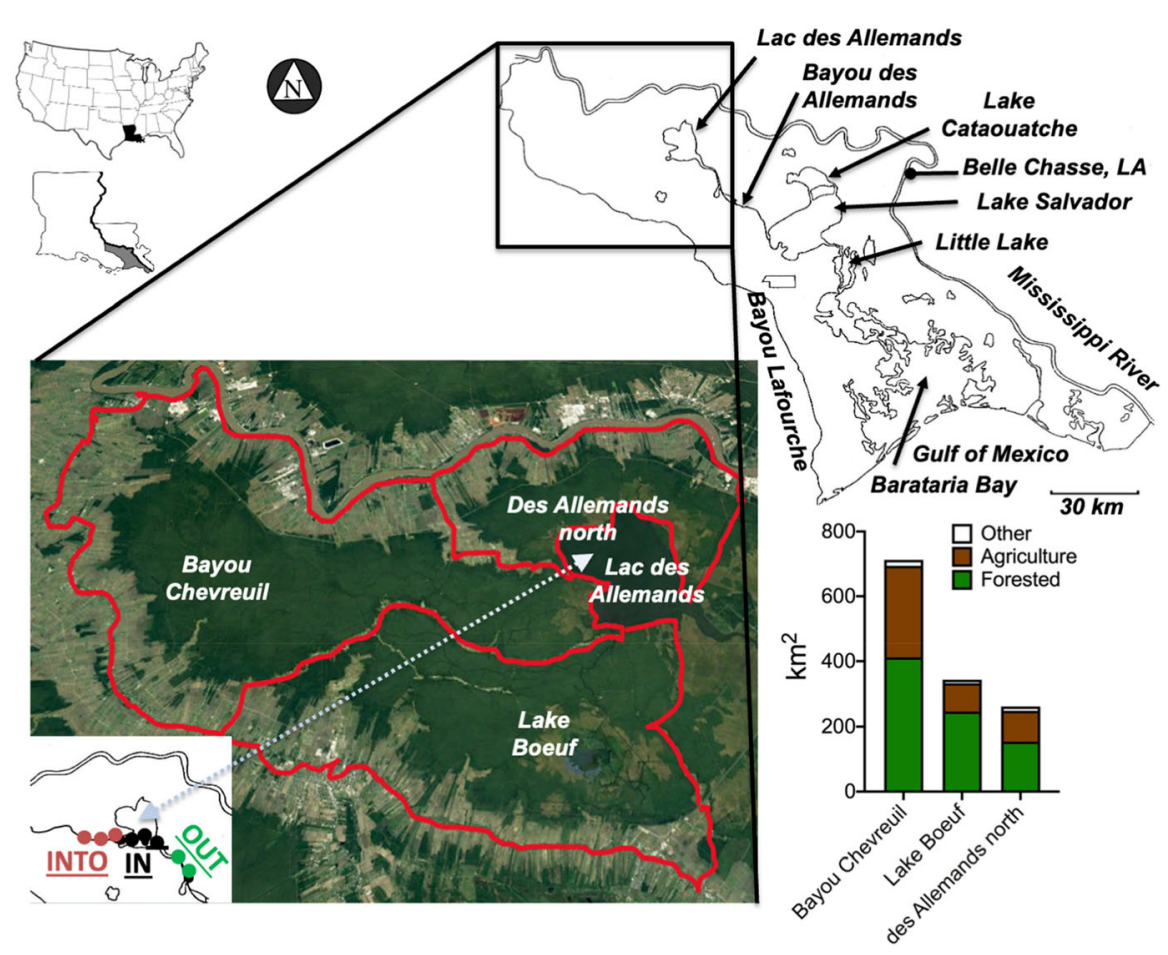

watershed and is drained by the stream 'Bayou des Allemands' that joins Lake Salvador to flow into Little Lake and then into the Barataria Bay estuary where water exchanges with the Gulf of Mexico at the seaward end. The average water depth in Lac des Allemands is $1.5 \mathrm{~m}$ and it is polymictic. The minor diurnal or semi-diurnal tides average $0.03 \mathrm{~m}$ and that are significantly modified by winds. It takes an average of 50 to 70 days for a pulse of tracer (pulse residence time, defined as $\mathrm{e}^{-1}$ ) instantaneously added to a water body to decline to $37 \%$ of the original concentration in the middle of Lac des Allemands (Das, 2010). Butler (1975) calculated a residence time of 2 months.

Ninety-seven percent of the Lac des Allemands watershed in 2016 was forested and agricultural area (Fig. 1) which is similar to what it was in 1975 (Hopkinson, 1979; Electronic Supplementary Table S1). Thirty-five percent is agricultural area that has some pasture but is mostly sugarcane agriculture (Lindau et al., 1997) based on hybrids derived from the genus Saccharum (Bischoff \& Gravois, 2004). The agricultural area in the entire Barataria Basin is predominately in the Lac des Allemands watershed. The wetland area is a mixed bald cypress-water tupelo (Taxodium distichum-Nyssa aquatica) swamp. Less than $3 \%$ of the total land cover is urbanized.
The area of the Bayou Chevreuil sub-section of the Lac des Allemands watershed (Fig. 1) is $54 \%$ of the total watershed and has $51 \%, 61 \%$, and $44 \%$ of the forested, agriculture, or rural/urban land in the whole watershed, respectively (Supplementary Information Table S1). The Bayou Boeuf sub-section drains 34\% of the Lac des Allemands watershed and contains 19\% of the agricultural land (Fig. 1; Table S1). The percent agricultural land in the Bayou Chevreuil sub-section is 3.2 times larger than in the adjoining two other subsections sub-section (Fig. 1). The yields (mass per area) of nitrate + nitrite and phosphate from the Bayou Boeuf subsection were $77 \%$ and $51 \%$, respectively, of the concentrations in the Bayou Chevreuil subsection in 1973 and 1974 (Butler, 1975), which is consistent with the assumption that $\mathrm{P}$ is mostly from an agricultural source. The land use in the unsampled $20 \%$ of the entire watershed (des Allemands north subsection) has about $20 \%$ agricultural land. The $\mathrm{N}$ and $\mathrm{P}$ yields per area from the Lac des Allemands north and Bayou Boeuf subsections, therefore, are expected to be the about the same or lower than from the Bayou Chevreuil sub-section. Groundwater is not a significant source of phosphorus and nitrogen into the Lac des Allemands watershed because of both the low quantity of groundwater flow in the watershed and its 
phosphorus and nitrogen concentrations relative to Bayou Chevreuil (Supplemental Information). Precipitation inputs are also relatively small compared to the fertilizer-sourced P loadings (Supplemental Information).

Lantz (1970), Butler (1975), and Stow et al. (1985) commented on the presence of blue-green algae in Lac des Allemands. Garcia et al. (2010) found that Microcystis sp. dominated all other phytoplankton in Lac des Allemands in 10 sampling trips from 2006 to 2007, except for in December when Raphidiopsis/ Cylindrospermopsis spp. dominated. Ten liter mesocosm experiments on nutrient limitation in lake water were conducted by Ren et al. (2009) using lake water containing N-fixing Anabaena spp. and other cyanobacteria. Other mesocosm experiments used additions of Mississippi River water (Ren et al., 2020). N, more than $P$ additions, constrained algal growth in both sets of experiments, and blue-green algae could successfully compete with diatoms under silicate-replete conditions (Ren et al., 2009, 2020).

\section{Sample collection}

The water quality sampling came from 2 stations draining Lac des Allemands (Bayou Des Allemands (\#30-31), 3 stations in Lac des Allemands (\#32-34), and 3 stations in Bayou Chevreuil (\#35-37) that enters into it on the western side (Fig. 1). We collected samples monthly from January 1994 through December 2016 for a total of 267 monthly regular trips and 4 additional bi-monthly trips. Sample collection is described in greater detail by Turner et al. (2019). Briefly, we collected surface water in pre-rinsed Nalgene bottles, transported them in a cooler to the laboratory within $3 \mathrm{~h}$, where they were filtered upon arrival to determine Chl $a$ concentration or frozen for later analysis of the inorganic and organic fractions. The phosphate concentration is considered a relative concentration because freezing samples may result in a potential $10 \%$ increase in the absolute concentration of phosphate (Chapman \& Mostert, 1990).

\section{Water quality analysis}

The water quality instruments used and analyses conducted are those described in Turner et al. (2019). Salinity (psu) was measured in the laboratory or field with a digital chloridometer or Yellow Springs, Inc. conductivity/temperature meter. Samples for suspended matter were filtered through pre-weighed grade $\mathrm{C}$ borosilicate glass fiber filters $(1.1 \mu \mathrm{m})$ that were pre-combusted at $550{ }^{\circ} \mathrm{C}$ for $1 \mathrm{~h}$. The postfiltration filters were first dried at $60{ }^{\circ} \mathrm{C}$ for $24 \mathrm{~h}$ and then re-weighed to determine the total suspended matter (TSS), heated to $550{ }^{\circ} \mathrm{C}$ for $1.0 \mathrm{~h}$, and then reweighed again to determine the amount of inorganic and organic suspended matter. A Secchi disk (SD) was used to measure light penetration $(\mathrm{cm})$.

Unfiltered water samples were frozen until determination of dissolved forms of nitrogen $(\mathrm{N})$, phosphorus $(\mathrm{P})$, and silicate (DSi) using either a Technicon Autoanalyzer II (USEPA Method 353.2 for ammonium and nitrate + nitrite (DIN), USEPA Method 365.2 for phosphate (DIP), and Technicon Method 186-72W/B for silicate) or a Lachat Quick-Chem 8000 Flow Injection Analyzer using the Lachat Methods approved by USEPA: method 31-107-06-1-B for ammonium, method 31-107-04-1-C for nitrate + nitrite (herein 'nitrate'), method 31-115-01-1-H for inorganic phosphate (DIP), and method 31-114-27-1C for DSi. A 5-point standard curve was used and QC standards were analyzed before, during, and after each set of samples analyzed. Total nitrogen (TN) and total phosphorus (TP) concentrations were measured using a Technicon Autoanalyzer II or LaChat Quick-Chem after persulfate wet oxidation digestion (Raimbault et al., 1999). The TP and TN analyses were done on unfiltered samples. The concentration of total carbon (TC) was measured using a Shimadzu ${ }^{\circledR}$ TOC-5000A Analyzer. Total organic carbon (TOC) was measured by acidifying samples with $\mathrm{HCl}$ and then sparging before analysis to remove the inorganic carbon (IC). The coefficient of determination for the standard curve was $>0.98$ for all nutrient analyses.

Chl $a$ concentration estimation used a Turner Model 10 fluorometer calibrated with a chemical supply house standard measured with a spectrophotometer. Samples were read before and after acidification (Lohrenz et al., 1999). The annual number of occurrences when Chl $a$ exceeded either $>50$ or $100 \mu \mathrm{g} \mathrm{l}^{-1}$ (blooms) was enumerated for the lake.

\section{Statistical analyses}

We used Prism 8.0c software (c) 2020 (GraphPad Software, Inc., La Jolla, CA) for statistical analyses. The mean and the standard error of the mean $(\mu \pm 1$ 
SEM) for each water quality parameter was calculated for each year or month for three station groupings: into, within, and going out of Lac des Allemands. The concentration of TN or TP entering or leaving the lake was compared to that within the lake for monthly and annual averages. Log transforms were made for graphing purposes. Violin plots of the TN:TP molar ratios for four ranges of $\mathrm{Chl} a$ concentration visually describe the width of the distribution of points in proportional to the number of points at that $\mathrm{Y}$ value. The TN:TP molar ratios in Lac des Allemands were computed for each sampling trip with complementary pigment data $(n=195)$ and separated into sub-sets using 4 ranges of the total $\mathrm{Chl} a$ concentration $(\mu \mathrm{g}$ $\left.1^{-1}\right): 0$ to $25,>25$ to $<50,>50$ to 100 , and $>100$ ( $n=36,65,41,25,14,8$, and 6 , respectively). The purpose was to examine how the variability in the $\mathrm{TN}$ :TP ratio and its average was related to the average $\mathrm{Chl} a$ concentration. An ordinary one-way ANOVA was performed along with a Brown-Forsythe test of equal variance and a Kruskal-Wallis test for nonparametric distributions to test if the TN:TP ratios in the four groups were different from each other.

\section{Fertilizer use}

Alexander and Smith (1990), Gronberg and Spahr (2012), and Brakebill and Gronberg (2017) compiled the amount of nitrogen and phosphorus fertilizer used in agriculture for the three parishes surrounding Lac des Allemands (St. John, St. James, and Lafourche) from 1945 to 2012 (Electronic Supplementary Fig. S1). These parishes overlap watershed boundaries and therefore estimates of fertilizer sales in a parish do not precisely represent fertilizer use in only the Lac des Allemands watershed. The annual fertilizer use data were compared to water quality measurements for years in which the average annual water quality collections included at least 11 months of data.

\section{Little Lake's Chlorophyll a concentration}

The watershed-wide amounts of fertilizer were compared to the concentrations of Chl $a$ in Little Lake from 1975 to 1998 that were determined as part of monthly monitoring conducted by the Louisiana Department of Wildlife and Fisheries (LDWF). The Little Lake Chl $a$ data set are not found online or at the LDWF offices, but we retained the data set a few years after they were collected; the data are reproduced in the Supplementary Information (Table S2). It is important to point out that the Davis Pond diversion of Mississippi River water into the eastern end of Lake Salvador, then Little Lake, began after the last date of this Little Lake data set. The Davis Pond diversion could not have, therefore, any influence on the data analysis discussed below.

\section{Results}

Annual averages between months

The concentration of suspended matter $\left(\mathrm{mg}^{-1}\right)$, total carbon $\left(\mathrm{mg} \mathrm{l}^{-1}\right)$, TP $\left(\mu \mathrm{mol} \mathrm{l}^{-1}\right)$, DSi $\left(\mu \mathrm{mol} \mathrm{l}^{-1}\right)$, DIP $\left(\mu \mathrm{mol} 1^{-1}\right)$, and DIN $\left(\mu \mathrm{mol} 1^{-1}\right)$ were higher in the water entering Lac des Allemands compared to those in the lake and those leaving the lake (Fig. 2A, D, E, $\mathrm{G}, \mathrm{H}$, and I). The suspended sediment matter concentration in water leaving the lake was 59 percent of that in water entering the lake (13.7 and $23.2 \mathrm{mg} \mathrm{l}^{-1}$, respectively). The sediment trapping (41\%) in the lake contributed to the Secchi disk depth (SDD; m) increasing from an average of $0.43 \mathrm{~m}$ into the lake to $0.52 \mathrm{~m}$ in the lake and $0.52 \mathrm{~m}$ leaving the lake (Fig. 2B).

The average monthly concentration of Chl $a(76 \mu \mathrm{g}$ $\left.1^{-1}\right)$ and TN $\left(76 \mu \mathrm{mol} \mathrm{l}^{-1}\right)$ in the lake was $123 \%$ of the concentration in the water entering it and similar to that in water leaving it $\left(79 \mu \mathrm{g} 1^{-1}\right.$ and $94 \mu \mathrm{mol} \mathrm{l}^{-1}$, respectively; Fig. $2 \mathrm{C}$ and I). The monthly peak in $\mathrm{Chl}$ a concentration (Fig. 2C) was coincided noticeably with the maximum monthly secchi disk depth (Fig. 2B), implying light limitation. The total carbon concentration in the lake was $84 \%$ of that entering the lake, which was 3\% lower after leaving the lake (Fig. 2D). The amount of TP leaving the lake was 54\% of the average concentration entering it (Fig. 2E). The lake had a net gain (19\%) in the concentration of TN compared to the concentration in the incoming water, but the concentration leaving the lake, however, was $123 \%$ of the $\mathrm{TN}$ concentration entering the lake (Fig. 2F). The 22 years of data document that the lake is a net sink for TC and TP, but a source of TN (Table 1).

These disproportionate changes resulted in the TN:TP molar ratios going from 9.5:1 as water entered the lake to $16.5: 1$ within the lake and 21.5:1 after 


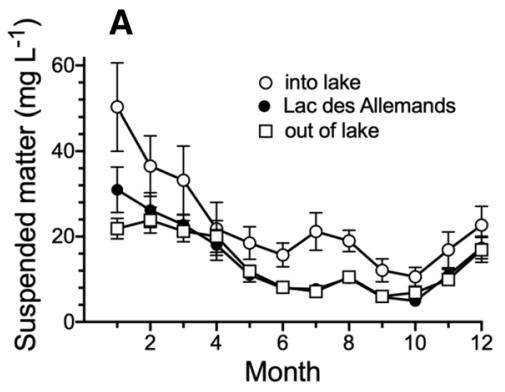

D

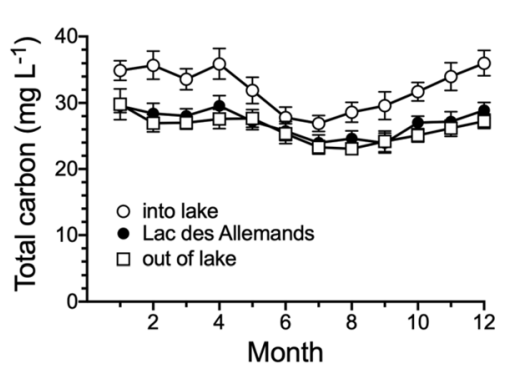

G

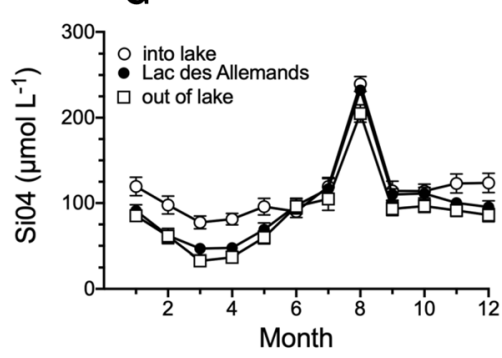

B

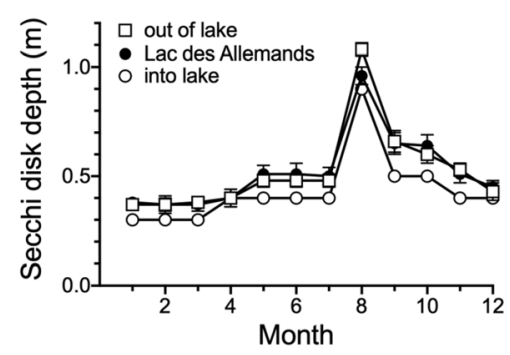

E

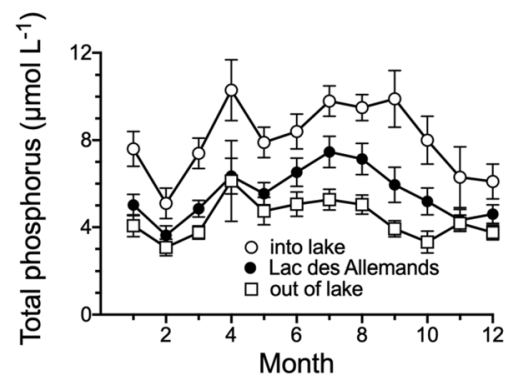

H

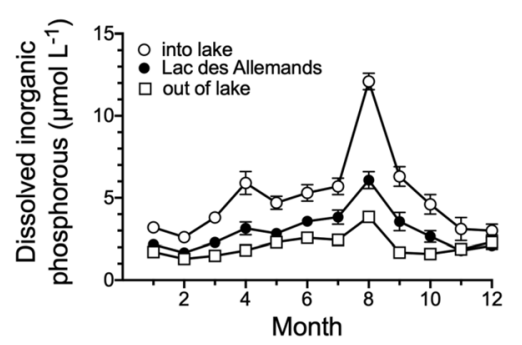

C

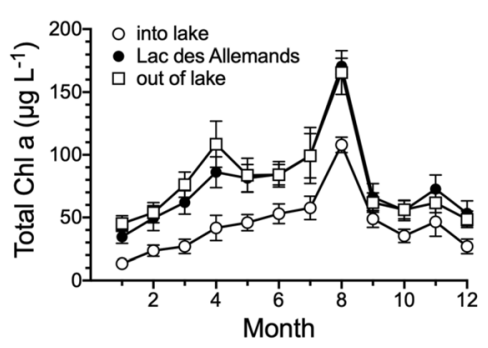

$\mathbf{F}$

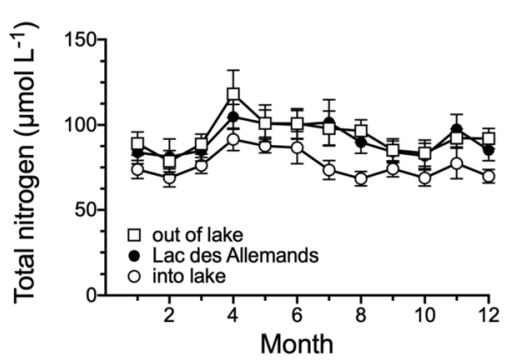

I

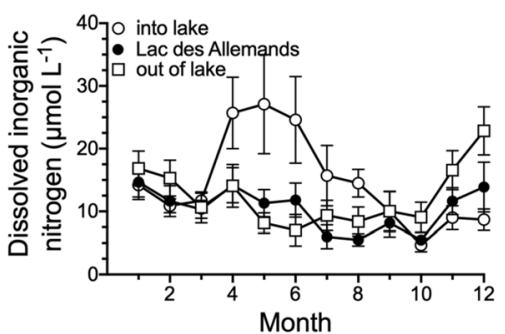

Fig. 2 The monthly average concentrations $(\mu \pm 1$ SEM) in water entering the lake in Bayou Chevreuil, within Lac des Allemands, and exiting the lake within Bayou des Allemands from 1994 to 2016. A Suspended matter $\left(\mathrm{mg} \mathrm{l}^{-1}\right)$. B Secchi disk depth (m). C Total Chl $a\left(\mu \mathrm{g}^{-1}\right)$. D Total carbon $\left(\mathrm{mg} \mathrm{l}^{-1}\right)$. E Total phosphorous $\left(\mu \mathrm{mol} 1^{-1}\right)$. F Total nitrogen $\left(\mu \mathrm{mol} 1^{-1}\right)$. G Silicate $\left(\mu \mathrm{mol} 1^{-1}\right)$. H Dissolved inorganic phosphate $(\mu \mathrm{mol}$ $\left.1^{-1}\right)$. I Dissolved inorganic nitrogen $\left(\mu \mathrm{mol} \mathrm{l}^{-1}\right)$

Table 1 The average percent change in the concentration of TC, TN, and TP in lake water and water leaving Lac des Allemands compared to water entering the lake

\begin{tabular}{lccc}
\hline & Total carbon $\left(\mu \mathrm{g} 1^{1}\right)(\%)$ & Total nitrogen $\left(\mu \mathrm{g} 1^{1}\right)$ & Total phosphorous $\left(\mu \mathrm{g} 1^{1}\right)$ \\
\hline Entering & 100 & 100 & 100 \\
Within & 84 & 120 & 69 \\
Outgoing & 81 & 123 & 54 \\
\hline
\end{tabular}

leaving the lake. These patterns are consistent with Stow et al.'s (1985) conclusion that phosphorus was deposited in lake sediments, and that nitrogen fixation was occurring in the lake. The concentrations of DSi, DIP, and DIN were higher in Bayou Chevreuil than in the lake or leaving it (Fig. 2G-I), and the DIN concentration entering the lake was highest in the spring and summer (Fig. 2I). The molar ratio of DIN:DIP for all months was never greater than 20:1 and dropped to 1:1 in August. The average DIN:DIP 
molar ratio was 2.9:1 in water entering the lake, 3.5:1 within the lake, and 6.0:1 in water just leaving the lake, and the average DSi:DIN molar ratio in water entering the lake was 7.9:1, 9.5:1 within the lake, and 7.1:1 after leaving the lake (not shown).

The monthly concentration of Chl $a$ in water in the lake is strongly related to the concentration of DIP entering the lake through Bayou Chevreuil $\left(R^{2}=0.85\right.$; Fig. $3 \mathrm{~A})$ and in the lake $\left(R^{2}=0.85\right.$; Fig. $\left.3 \mathrm{~A}\right)$. The concentration of DIP in the lake was less strongly related to the $\mathrm{Chl} a$ concentration in the lake $\left(R^{2}=0.58\right.$; Fig. 3B). The monthly Chl $a$ concentration in Bayou Chevreuil was insignificantly related to the concentration of TP going into the lake (Fig. 3C), whereas as the concentration of $\mathrm{Chl}$ a in the lake was strongly correlated with the TP concentration in the lake $\left(R^{2}=0.83\right.$; Fig. 3D). The concentration of $\mathrm{Chl}$ $a$ was not significantly correlated to the concentration of TN in Bayou Chevreuil (Fig. 3E) and there was no significant relationship between the monthly lake $\mathrm{Chl}$ $a$ concentration and TN concentration (Fig. 3F). A test to detect a difference between the slopes and intercept of the regression lines in Fig. $3 \mathrm{~A}$ and $\mathrm{D}$ with and without the high value revealed no difference. There was, however, a significant relationship between the $\mathrm{TN}$ and Chl $a$ concentration if the high value (170 $\mu \mathrm{g}$ Chl $a 1^{-1}$ ) in panel Fig. 3F was omitted from the regression analysis. There was no significant
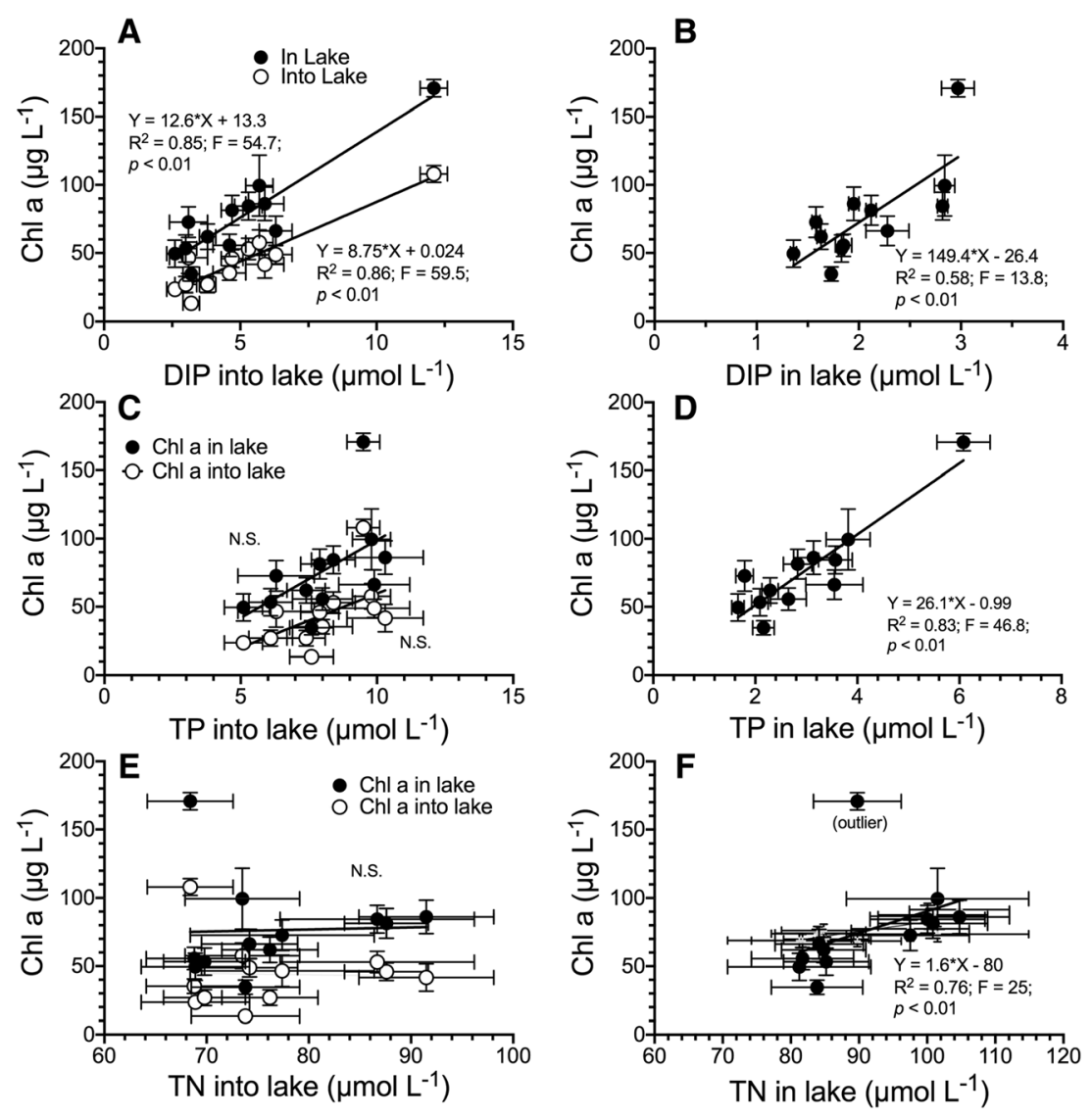

Fig. 3 The relationship between the 12 monthly molar concentrations of DIP, TP, and TN in Bayou Chevreuil (into the lake) vs. The Chl $a$ concentrations in Bayou Chevreuil and Lac des Allemands ( $\mu \mathrm{g} \mathrm{Chl} a 1^{-1}$ ). A DIP concentration in Bayou Chevreuil vs. Chl $a$ in Bayou Chevreuil and Lac des Allemands. B DIP concentration vs. Chl $a$ in Lac des Allemands. C TP concentration in Bayou Chevreuil vs. Chl $a$ in Bayou Chevreuil and Lac des Allemands. D TP concentration vs. Chl

$a$ concentration in Lac des Allemands. E TN concentration in Bayou Chevreuil vs. Chl $a$ in Bayou Chevreuil and Lac des Allemands. F TN concentration vs. Chl $a$ concentration in Lac des Allemands. The error bars are the $\mu \pm 1$ SEM. There was no difference between the slopes or intercepts in the individual equations if the high value was removed from the analysis in A or D. N.S. not significant 
relationship between the monthly concentrations of DIN in Bayou Chevreuil and Chl $a$ concentrations in the bayou or lake $(P>0.35$ and 0.54 , respectively), or between DIN concentrations in the lake and lake $\mathrm{Chl}$ $a$ concentrations $(P=0.08)$.

TP concentration, land use, and Chl $a$

There were 10 years with fertilizer data to match the 22 sampling years with water quality data. The TP concentration in Bayou Chevreuil entering the lake is directly related to the annual amounts of $\mathrm{P}$ fertilizer used in the surrounding 3 parishes (Fig. 4). A simple linear regression had an adjusted $R^{2}=0.74$ $(P<0.01)$.

The average annual increase in the TN concentration after water enters Lac des Allemands (concentration in the lake minus concentration in the lake) is directly related to the average annual concentration of TP or phosphate going into the lake (Fig. $5 \mathrm{~A}$ and B, respectively), but not to variability in the nitrate or $\mathrm{TN}$ concentration in the incoming water (Fig. 5C and D, respectively).
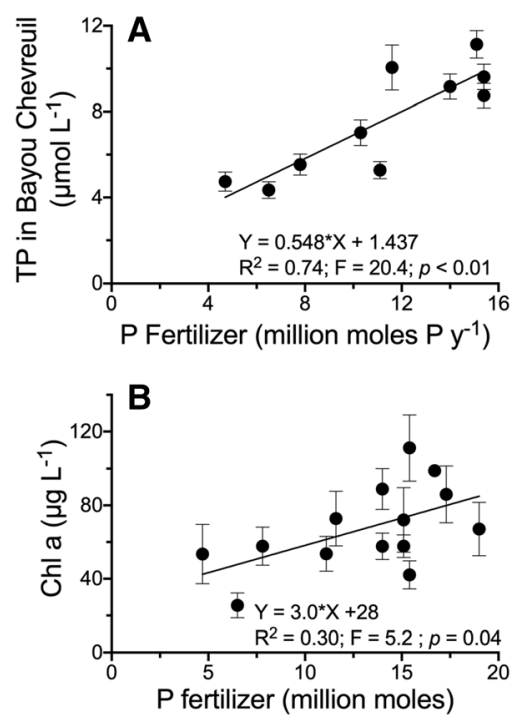

Fig. 4 The relationship between the annual amount of $\mathrm{P}$ fertilizer used (million moles $\mathrm{P}$ year ${ }^{-1}$ ) in the three local parishes from 1994 to 2012 and $\mathbf{A}$ the average annual concentration of TP $\left(\mu \mathrm{mol} 1^{-1}\right)$ in Bayou Chevreuil, and $\mathbf{B}$ the Chl $a$ concentration in Lac des Allemands. The error bars are the $\mu \pm 1$ SEM
Chl $a$, TN, and TP

There was a direct relationship between the lake's Chl $a$ concentration and both TN and TP concentrations (Fig. 6 A). All Chl a values except one occurred when the TN:TP molar ratio was $<40: 1$. The median TN:TP molar ratio was $16.8: 1$ and the individual values ranged from $6.5: 1$ to $49.6: 1(n=195)$. Grouping the Chl. a data into categories $(<25,25-50,50-100$, and $>100 \mu \mathrm{g} \mathrm{l}^{-1}$ ) showed no differences in the corresponding ratios of TN:TP $(P=0.66)$, but the range of individual values within each group declined as the Chl $a$ concentration increased (Fig. 6B).

The Chl $a$ concentrations in Fig. 6A lot are compared to the $10 \mu \mathrm{g} \mathrm{MC} 1^{-1}$ threshold found in 246 Canadian Lakes with concurrent TN, TP, and MC measurements (Orihel et al., 2012). Their $10 \mu \mathrm{g} \mathrm{MC}$ $1^{-1}$ threshold was exceeded in all samples from Lac des Allemands that had a Chl a concentration $>50 \mu \mathrm{g}$ $1^{-1}$ (Fig. 6A).

The average annual concentration of Chl $a$ in Little Lake, $50 \mathrm{~km}$ downstream from Lac des Allemands (Fig. 1), was inversely related to $\mathrm{N}$ fertilizer use in the Barataria watershed $\left(R^{2}=0.32\right.$; Fig. $\left.7 \mathrm{~A}\right)$, but positively related to $\mathrm{P}$ fertilizer use $\left(R^{2}=0.57\right.$; Fig. 7B $)$ and had an intercept less than zero. The declining $\mathrm{P}$ fertilizer use when TN fertilizer use increased had the effect of raising the TN:TP ratio (Fig. 7C; Fig. S1). A multiple linear regression analysis predicting the $\mathrm{Chl}$ $a$ concentration in Little Lake that included the TN and TP fertilizer use had an $R^{2}=0.62$ (Fig. 7D), which is only slightly higher than using only $\mathrm{P}$ fertilizer use (0.57; Fig. 7B) indicating that the TN use was a minor independent variable explaining the relationship.

\section{Discussion}

\section{Consequences of $\mathrm{P}$ fertilizer use}

The dominant source of TP in Bayou Chevreuil, which feeds directly into Lac des Allemands, is fertilizer use in the watershed (Butler, 1975; Hopkinson, 1979; Stowe 1985; Fig. 3), which is common where there is industrialized row-crop farming (Vanni et al., 2011; Bunting et al., 2016; Boardmann et al., 2019). Hopkinson's (1979) modeling result was that $75 \%$ of the $\mathrm{N}$ and $95 \%$ of the $\mathrm{P}$ came from agricultural land in the des Allemands watershed in 1975. Regardless of 
Fig. 5 The relationship between the average annual increase in the molar concentration of $\mathrm{N}$ after water enters Lac des Allemands and the average annual concentration going into the lake of A DIP, B TP, C nitrate, and $\mathbf{D}$ TN. The line for panels $\mathbf{A}$ and $\mathbf{B}$ is a $\log$ : linear fit of the data. The error bars are the $\mu \pm 1$

SEM of the average concentration for each year. N.S. not significant
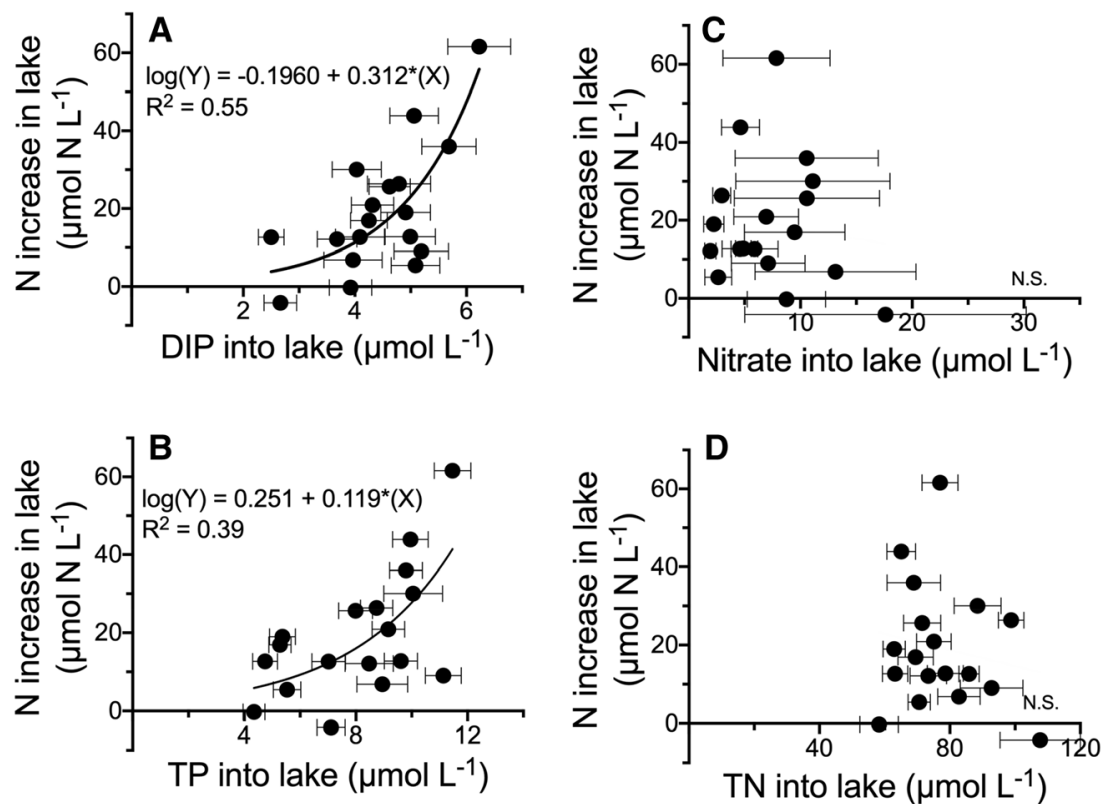

$\mathrm{TN}$ into lake $\left(\mu \mathrm{mol} \mathrm{L}^{-1}\right)$
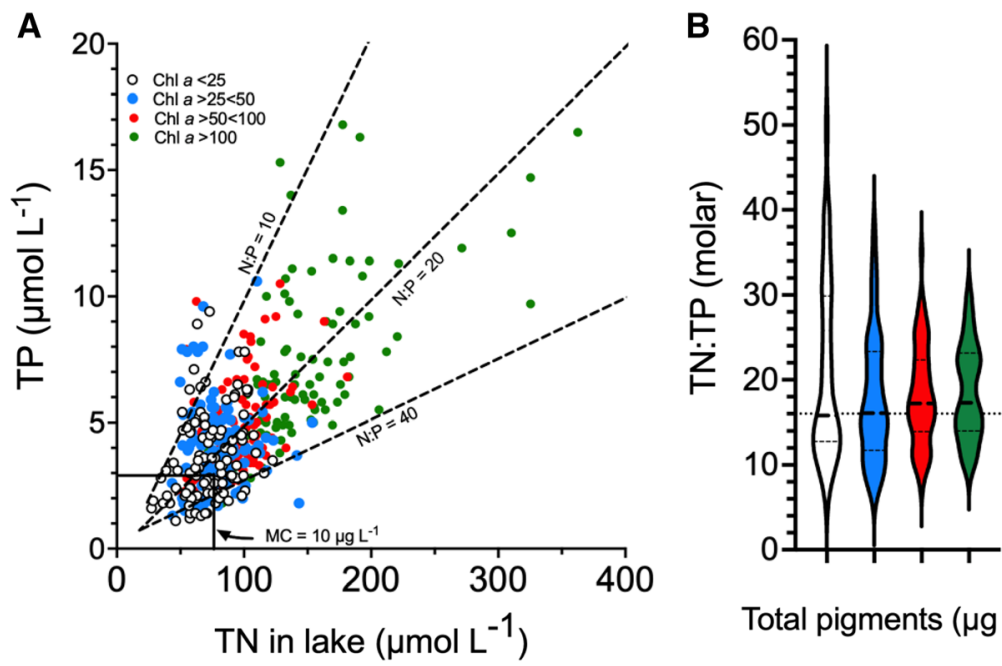

Total pigments $\left(\mu \mathrm{g} \mathrm{L}^{-1}\right)$

Fig. 6 The relationship of $\mathrm{TN}$ and $\mathrm{TP}$ concentrations in lake water for 4 different ranges of Chl $a$ concentration $\left(\mu \mathrm{g}^{-1}\right)$ among all sampling trips. A The diagonal dotted lines across all groups show the TN:TP molar ratios of 10:1, 20:1, and 40:1. A comparison is made for the threshold concentrations of $\mathrm{TN}$ and

source, the variations in the concentration of Chl $a$ in Bayou Chevreuil and Lac des Allemands are directly related to the average annual concentration of TP and DIP in Bayou Cheuvril (Fig. 3). The variations in the annual Chl $a$ concentrations in Little Lake, downstream of Lac des Allemands, are directly correlated with fertilizer use (Fig. 7). The indirect relationship of
TP where the microcystin concentration is $10 \mu \mathrm{g} \mathrm{MC} \cdot \mathrm{l}^{-1}$ in 246 Canadian Lakes (from Orihel et al., 2012). B A violin plot of data in the four quartiles. The dotted line is the 16:1::TN:TP molar ratio. There are no differences between the four groups

Chl $a$ and $\mathrm{N}$ fertilizer use in Little Lake may be because the $\mathrm{P}$ fertilizer use was declining simultaneously, but in different proportional amounts as $\mathrm{N}$ fertilizer use went up. What appeared to be an inverse relationship with $\mathrm{N}$ fertilizer may have been indirectly influenced by the declining $\mathrm{P}$ fertilizer use. A multiple regression analysis describing the $\mathrm{Chl} a$ concentration 
Fig. 7 The relationships between the annual average concentration of pigments in Little Lake $\left(\mu \mathrm{g} \mathrm{l}^{-1}\right)$ and the $\mathrm{P}$ or $\mathrm{N}$ fertilizer use in the watershed. A Nitrogen fertilizer use and the annual Chl $a$ concentration.

B Phosphorous fertilizer use and the annual $\mathrm{Chl}$ $a$ concentration. $\mathrm{C} \mathrm{N}: \mathrm{P}$ molar ratio of the fertilizer use over time with the data interval for $\mathrm{Chl}$ $a$ concentration data in Little Lake. D The Chl $a$ concentration predicted by the multiple regression equation that included the million moles of $\mathrm{N}$ and $\mathrm{P}$ fertilizer use
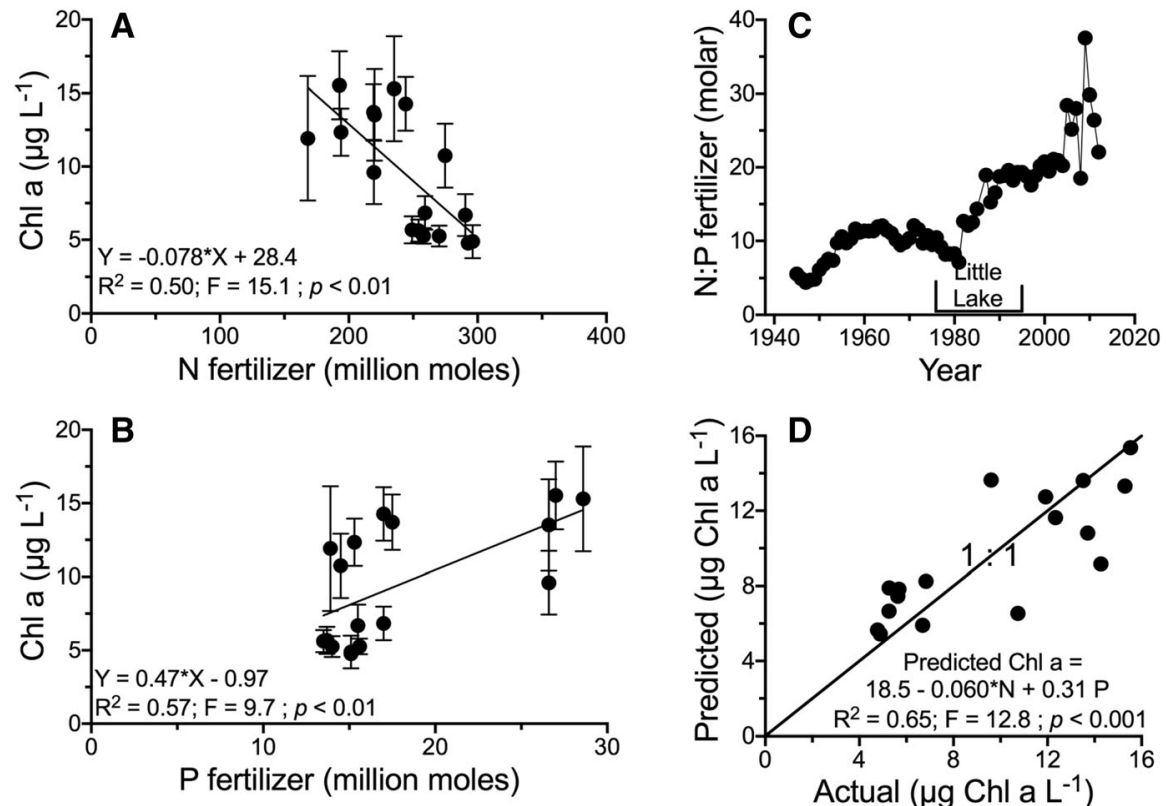

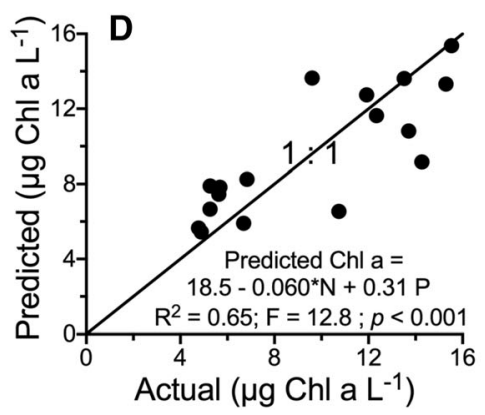

in Little Lake as the dependent variable, and TN and TP use and the TN:TP ratio as the independent variables, was significant for only TP use-it was a simple linear relationship. The Davis Pond diversion of Mississippi River water into the eastern end of Lake Salvador, then Little Lake, began after the last date of this Little Lake data set. The Davis Pond diversion could not have, therefore, any influence on the data analysis discussed below.

We conclude that nitrogen accumulation in Little Lake and Lac des Allemands is limited, but not exclusively, by the phosphorus concentration entering both lakes. The phosphorus and Chl $a$ concentrations are driven by the use of $\mathrm{P}$ fertilizer in the watershed. This has some relevance to carbon sequestration in the wetlands because wetland fertilization can change soils from a sink to a source for $\mathrm{N}_{2} \mathrm{O}$ as the microbes responsible for $\mathrm{N}$ transformations are stimulated by $\mathrm{P}$ supplies (Sundareshwar and Morris (1999). Chronic enrichment offsets the reduction in global warming potential from sequestering carbon in soil (Chmura et al., 2016).

\section{Algal toxicity}

A pregnant question for this analysis is whether the increased Chl $a$ accumulation includes harmful algal. Garcia et al. (2010) found microcystins in both surface water and blue crab tissue in Lac des Allemands and that microcystin concentrations (MC) exceeded World Health Organization guidelines (WHO, 2020) for a tolerable lifetime daily intake of $1.0 \mu \mathrm{g} \mathrm{MC}^{-1}$ and a daily drinking water intake of $12 \mu \mathrm{g} \mathrm{MC} \cdot \mathrm{l}^{-1}$. Others have shown that the concentration of $\mathrm{MC}$ is positively related to the concentration of $\mathrm{Chl} a$ (Oh et al., 2001), and both Chl $a$ and TP (Kotak et al., 1996; Rinta-Kanto et al., 2009). Orihel et al. (2012) found that the risk of exceeding water quality guidelines was greatest when the TN:TP ratio was less than 20:1 which is when the TN and TP concentrations and molar ratios of TN:TP were within the range found in Lake des Allemands. If we assume that most of the Chl $a$ in Lake des Allemands is indeed from MC-producing cyanobacteria, and that $\mathrm{MC}: \mathrm{Chl} a$ ratios found elsewhere are possible in this lake, then this suggests a risk of high MC concentrations which, however, merits a survey.

\section{Nitrogen transport downstream}

The net gain of $\mathrm{N}$ in lake water leaves the lake and toward the coast where Turner et al. (2019) showed that the key mechanism for the significant decline of TN concentrations downstream is not denitrification, but dilution with estuarine waters. The nitrogen accumulated in Lac des Allemands feeds downstream waterbodies, while inorganic and organic forms 
transform from one to another along the way to the coast. P abatement into Lac des Allemands would presumably result in less $\mathrm{N}$ being produced, which is a different restoration trajectory from that described by Conley et al. (2009) and Finlay et al. (2013). Both of these papers discuss the quandary of controlling eutrophication with $\mathrm{P}$ restrictions, assuming that there would be less algal biomass sequestered in lake sediments with decreased $\mathrm{P}$ loading and less $\mathrm{N}$ deposited there too. Reducing $\mathrm{N}$ burial, they argued, results in more $\mathrm{N}$ transport downstream where it creates eutrophication problems, provided that $\mathrm{N}$ and not $\mathrm{P}$ is limiting in these lakes. Ratmaya et al. (2019) found this to be the case in the Loire and Vilaine rivers. As phosphorus concentration decreased upstream and less $\mathrm{N}$ was deposited in sediments, and then the nitrogen moved downstream. But this narrative is the opposite of what happened in Lac des Allemands. We note that all the lakes that Finlay et al. (2013) examined having a negative $\mathrm{N}$ removal rate also had a water residence time of less than 2 months, as does Lac des Allemands. The faster turnover time could influence decomposition rates or particle suspension. The turbulence in this shallow, wind-exposed lake could also keep nitrogen-fixing bacteria illuminated.

Results from the whole lake compared to mesocosms

The analyses of the data on the concentrations of substances in the water entering, within, and leaving the lake uncovered significant correlations supportive of the argument that $\mathrm{P}$ loading limited the net accumulations of phytoplankton and $\mathrm{N}$ within lake water. These results were different from the interpretation of mesocosm experiments conducted by Ren et al. (2009). Ren et al. (2009) used nutrient addition/ deletion bioassays at Redfield ratios to investigate the same phenomena in January, April, and July 2004. They suggested that there was a nitrogen and phosphorus limitation in the bioassays in January and April, and $\mathrm{N}$ limitation in July. We speculate that reasons for the apparent differences between the results of this study and Ren et al. (2009) are that Ren et al. used inorganic nutrient additions and did not measure changes in TN concentration, whereas we did, and that a container effect may have had some influence, including on creating unequal light attenuation in the mesocosm compared to in the lake. While neither of these studies measured $\mathrm{N}$ fixation rates, about $50 \%$ of biovolume was composed of heterocystous Anabaena (Ren et al., 2009) which makes it likely that $\mathrm{N}$ fixation was occurring. $\mathrm{N}$ fixation is an energetically expensive metabolic means for cyanobacteria to acquire N (Moisander et al., 2012) and so we agree with Ren et al. (2009) that nitrogenfixing cyanobacteria will use a nitrogen sources that are energetically easier to take up when the external $\mathrm{N}$ supply is enlarged. As a result, their growth is perhaps enhanced under the $\mathrm{N}$ enrichment with inorganic additions or higher $\mathrm{N}$ fixation. Whole-lake experiments have shown how $\mathrm{P}$ additions stimulated diazotrophic cyanobacteria "that fixed atmospheric $\mathrm{N}$ in sufficient quantities to utilize available $\mathrm{P}$, keeping the phytoplankton in a P limited state" (Higgins et al., 2018). Tropical reservoirs, for example, have Chl $a$ concentrations that are directly related to the TP concentration and $\mathrm{P}$ is the main nutrient controlling nitrogen fixation rates when cyanobacteria are present (Moutinho et al., 2021).

\section{Molar ratios}

In situations with high pigment concentrations $\left(>100 \mu \mathrm{g} \mathrm{Chl} \mathrm{a}^{-1}\right.$ ), the range of the molar TN:TP ratios narrowly grouped around 18.6:1, when compared to sub-grouping with a lowest pigment concentration $\left(<25 \mu \mathrm{g} \mathrm{Chl} \mathrm{a}{ }^{-1}\right)$ that had a wider range but similar ratio. The average ratio was similar to a peak in phytoplankton bloom numbers for the 37 stations sampled throughout the basin (Turner et al., 2019). The highest pigment concentrations occurred when the ratio was near a stable 'balanced growth' of the 'Redfield ratio.' This consistent stoichiometrically balanced growth suggests that both $\mathrm{N}$ and $\mathrm{P}$ are controlling influences on the accumulation of algal biomass, but only $\mathrm{N}$ can be introduced in situ (through nitrogen fixation), which leaves the potential for $\mathrm{P}$ to strongly influence $\mathrm{N}$ fixation which could explain the observed direct relationship between $\mathrm{P}$ and $\mathrm{Chl}$ $a$ concentrations. The nutrient ratios are in this sense, can be a consequence, not a cause, of algal biomass accumulation. 


\section{Conclusion}

These results are from an intensely sampled study of a $65 \mathrm{~km}^{2}$ lake with variable water quality strongly influenced by the surrounding agricultural landscape. This lake has similarities: the many densely packed row-crop agricultural landscape with extremely high concentrations of $\mathrm{N}$ and $\mathrm{P}$ in the streams entering the lake. These intensely farmed landscapes, once novel, have become more numerous over the last century. In this lake, more $\mathrm{N}$ accumulates in lake water than is denitrified or buried within it, and phosphorus limits algal production, phytoplankton biomass, nitrogen accumulation, and probably toxic community development. The fixation of nitrogen may have kept the phytoplankton in a $\mathrm{P}$ limited state. There are many reasons to concurrently reduce $\mathrm{N}$ sources to waterbodies but, in this lake and perhaps others in a similar landscape, reducing $\mathrm{P}$ appears to be the primary action needed to minimize algal biomass upstream and $\mathrm{N}$ loading into estuaries.

Acknowledgements We thank the dozens of students, staff, and faculty who assisted water sample collection and analyses, and especially G. Peterson and T.A. Oswald. Lauris Hollis provided constructive comments on an earlier draft.

Author contributions RET: Conceptualization, Methodology, Formal analysis, Investigation, Writing-Original draft preparation, Visualization, Supervision, Project administration, Funding acquisition. JML, CSM, EMS: Methodology, Investigation, Data Curation, Project administration.

Funding This analysis was supported by multiple funding sources, including the NOAA Coastal Ocean Program MULTISTRESS Award No. NA16OP2670 to Louisiana State University, NSF Rapid Grant DEB-1044599, Northern Gulf Institute, contract CPRA-2015-TO35-SB01-MB from The Water Institute of the Gulf, and a Gulf of Mexico Research Initiative grant to the Coastal Waters Consortium.

Data availability The data are available through the Gulf of Mexico Research Initiative Information \& Data Cooperative (GRIIDC) at https://data.gulfresearchinitiative.org (/data/ R4. $\times$ 264.000:0018).

Code availability Not applicable.

Declarations

Conflict of interest The authors declare that they have no known competing financial interests or personal relationships that could have appeared to influence the work reported in this paper.

Ethical approval Not applicable.

Consent to participate Not applicable.

Consent for publication Not applicable.

Open Access This article is licensed under a Creative Commons Attribution 4.0 International License, which permits use, sharing, adaptation, distribution and reproduction in any medium or format, as long as you give appropriate credit to the original author(s) and the source, provide a link to the Creative Commons licence, and indicate if changes were made. The images or other third party material in this article are included in the article's Creative Commons licence, unless indicated otherwise in a credit line to the material. If material is not included in the article's Creative Commons licence and your intended use is not permitted by statutory regulation or exceeds the permitted use, you will need to obtain permission directly from the copyright holder. To view a copy of this licence, visit http://creativecommons.org/licenses/by/4.0/.

\section{References}

Alexander, R. B. \& R. A. Smith, 1990. County level estimates of nitrogen and phosphorus fertilizer use in the United States, 1945 to 1985: U.S. Geological Survey Open-File Report 90-130, 12 p., available online at http://pubs.usgs.gov/of/ ofr $90130 /$.

Bertani, I., C. E. Steger, D. R. Obenour, G. L. Fahnenstiel, T. B. Bridgeman, T. H. Johnengen, M. J. Sayers, R. A. Shuchman \& D. Scavia, 2017. Tracking cyanobacteria blooms: do different monitoring approaches tell the same story? Science of the Total Environment 575: 294-308.

Bischoff, K. P. \& K. A. Gravois, 2004. The development of new sugarcane varieties at the LSU AgCenter. Journal American Society Sugar Cane Technologists 24: 142-155.

Boardman, E., M. Danesh-Yazdi, E. Foufoula-Georgiou, C. L. Dolph \& J. C. Finlay, 2019. Fertilizer, landscape features and climate regulate phosphorus retention and river export in diverse Midwestern watersheds. Biogeochemistry 146: 293-309.

Brakebill, J. W. \& J. M. Gronberg, 2017. County-level estimates of nitrogen and phosphorus from commercial fertilizer for the conterminous United States, 1987-2012: U.S. Geological Survey data release, https://doi.org/10.5066/ F7H41PKX.

Brender, J. D., P. J. Weyer, P. A. Romitti, P. Mohanty, M. U. Shinde, J. D. Brender, P. J. Weyer, P. A. Romitti, B. P. Mohanty, M. U. Shinde, A. M. Vuong, J. R. Sharkey, D. Dwivedi, S. A. Horel, J. Kantamneni, J. C. Huber Jr, Q. Zheng, M. M. Werler, K. E. Kelley, J. S. Griesenbeck, F. B. Zhan, P. H. Langlois, L. Suarez \& M. A Canfield, 2013. Prenatal nitrate intake from drinking water and selected birth defects in offspring of participants in the National 
Birth Defects Prevention Study. Environmental Health Perspectives 121: 1083-1089.

Bunting, L, Leavitt, P. R., G. L. Simpson, B. Wissel, K. R. Laird, B. F. Cumming, A. St Amand \& D. R. Engstrom, 2016. Increased variability and sudden ecosystem state change in Lake Winnipeg, Canada, caused by 20(th) century agriculture. Limnology and Oceanography 61: 2090-2107.

Butler, T. J., 1975. Aquatic metabolism and nutrient flux in a southern Louisiana swamp and lake system. M.S. Thesis, Louisiana State University.

Chapman, P. \& S. A. Mostert, 1990. Does freezing of nutrient samples cause analytical errors? South African Journal of Marine Science 9: 239-247.

Chmura, G. L., L. Kellman, L van Ardenne \& G. R. Guntenspergen, 2016. Greenhouse gas fluxes from salt marshes exposed to chronic nutrient enrichment. PLoS ONE 11: $\mathrm{e} 0149937$.

Chorus, I., A. Köhler, C. Beulker, J. Fastner, K van de Weyer, T. Hegewald \& M. Hupfer, 2020. Decades needed for ecosystem components to respond to a sharp and drastic phosphorus load reduction. Hydrobiologia 847: 4621-4651.

Chorus, I. \& E. Spijkerman, 2021. What Colin Reynolds could tell us about nutrient limitation, N:P ratios and eutrophication control. Hydrobiologia 848: 95-111.

Conley, D. J., H. W. Paerl, R. W. Howarth, D. F. Boesch, S. P. Seitzinger, K. E. Havens, C. Lancelot \& G. E. Likens, 2009. Controlling eutrophication: Nitrogen and phosphorus. Science 323: 1204-1205.

Das, A., 2010. Modeling the impacts of pulsed riverine inflows on hydrodynamics and water quality in the Barataria Bay estuary. Ph.D. Dissertation, Louisiana State University.

Dodds, W. K., W. W. Bouska, J. L. Eitzmann, T. J. Pilger, K. L. Pitts, A. J. Riley, J. T. Schloesser \& D. J. Thornbrugh, 2009. Eutrophication of U.S. freshwaters: analysis of potential economic damages. Environmental Science and Technology 43: 12-19.

Downing, J. A., S. B. Watson \& E. McCauley, 2001. Predicting cyanobacteria dominance in lakes. Canadian Journal of Fisheries and Aquatic Sciences 58: 1905-1908.

Downing, J. A., Y. T. Prairie, J. J. Cole, C. M. Duarte, L. J. Tranvik, R. G. Striegl, W. H. McDowell, P. Kortelainen, N. F. Caraco, J. M. Melack \& J. J. Middelburg, 2006. The global abundance and size distribution of lakes, ponds, and impoundments. Limnology and Oceanography 51: 2388-2397.

Finlay, J. C, G. E. Small, R. W. Sterner, 2013. Human influences on nitrogen removal in lakes. Science 342: 247-250.

Garcia, A. C., S. Bargu, P. Dash, N. N. Rabalais, M. Sutor, W. Morrison \& N. D. Walker, 2010. Evaluating the potential risk of microcystins to blue crab (Callinectes sapidus) fisheries and human health in a eutrophic estuary. Harmful Algae 9: 134-143.

Gronberg, J. M. \& N. E. Spahr, 2012. County-level estimates of nitrogen and phosphorus from commercial fertilizer for the Conterminous United States, 1987-2006: U.S. Geological Survey Scientific Investigations Report 2012-5207, 20 p. https://pubs.usgs.gov/sir/2012/5207/.

Harke, M. J., M. M. Steffen, C. J. Gobler, T. G. Otten, S. W. Wilhelm, S. A. Wood \& H. W. Paerl, 2016. A review of the global ecology, genomics, and biogeography of the toxic cyanobacterium, Microcystis spp. Harmful Algae 54: 4-20.

Higgins, S. N., M. J. Paterson, R. E. Hecky, D. W. Schindler, J. J., Venkiteswaran, D.L. Findlay, 2018. Biological nitrogen fixation prevents the response of a eutrophic lake to reduced loading of nitrogen: Evidence from a 46-year whole-lake experiment. Ecosystems 21: 1088-1100.

Hopkinson, C. S. 1979. The Relation of Man and Nature in Barataria Basin, Louisiana. Ph.D. Diss. Louisiana State University, Baton Rouge, LA.

Hutchinson, G. E., 1936. The Clear Mirror: A Pattern Of Life In Goa And In Indian Tibet. Cambridge University Press. Oxford.

Jeppesen, E., M. Sondergaard, J. P. Jensen, K. E. Havens, O. Anneville, L. Carvalho, M. F. Coveney, R. Deneke, M. T. Dokulil, B. Foy, D. Gerdeaux, S. E. Hampton, S. Hilt, K. Kangur, J. Kohler, E. H. H. R. Lammens, T. L. Lauridsen, M. Manca, M. R. Miracle, B. Moss, P. Noges, G. Persson, G. Phillips, R. Portielje, S. Romo, C. L. Schelske, D. Straile, I. Tatrai, E. Willen \& M. Winder, 2005. Lake responses to reduced nutrient loading - an analysis of contemporary long-term data from 35 case studies. Freshwater Biology 50: 1747-1771.

Keiser, D. A. \& J. S. Shapiro, 2017. Consequences of the Clean Water Act and the demand for water quality. National Bureau of Economic Research Paper 23070. Downloaded 5 May 2018, from: http://www.nber.org/papers/w23070.

Kotak, B. G., R. W. Zurawell, E. E. Prepa \& C. F. Holmes, 1996. Microcystin-LR concentration in aquatic food web compartments from lakes of varying trophic status. Canadian Journal of Fisheries and Aquatic Sciences 53: 1974-1985.

Lantz, K. E., 1970. An ecological survey of factors affecting fish production in a Louisiana natural lake and river. State of Louisiana Wildlife and Fisheries Commission Fisheries Bulletin 6. Baton Rouge, La.

Lewis, W. M., Jr. \& W. A. Wurtsbaugh, 2008. Control of lacustrine phytoplankton by nutrients: Erosion of the phosphorus paradigm. International Review of Hydrobiology 93: 446-465.

Lindau, C. W., R. D. DeLaune \& D. P. Alford, 1997. Monitoring nitrogen pollution from sugarcane runoff using $15 \mathrm{~N}$ analysis. Water, Air, and Soil Pollution 98: 389-399.

Lohrenz, S. E., G. L. Fahnenstiel, D. G. Redalje, G. A. Lang, M. J. Dagg, T. E. Whitledge \& Q. Dortch, 1999. Nutrient, irradiance, and mixing as factors regulating primary production in coastal waters impacted by the Mississippi River plume. Continental Shelf Research 19: 1113-1141.

Michalak, A. M., E. J. Anderson, D. Beletsky, S. Boland, N. S. Bosch, T. M. Bridgeman, J. D. Chaffin, K. Cho, R. Confesor, I. Daloglu, J. V. DePinto, M. A. Evans, G. L. Fahnenstiel, L. He, J. C. Ho, L. Jenkins, T. H. Johengen, K. C. Kuo, E. LaPorte, X. Liu, M. R. McWilliams, M. R. Moore, D. J. Posselt, R. P. Richards, D. Scavia, A. L. Steiner, E. Verhamme, D. M. Wright \& M. A. Zagorski, 2013. Record-setting algal bloom in Lake Erie caused by agricultural and meteorological trends consistent with expected future conditions. Proceedings of the National Academy of Sciences (USA) 110: 6448-6452.

Moisander, P. H., L. A. Cheshire, J. Braddy, E. S. Clandrino, M. Hoffman, M. F. Piehler \& H. W. Paerl, 2012. Faculative diazotrophy increases Cylindrospermopsis raciborskii 
competitiveness under fluctuating nitrogen availability. Federation of European Microbiological Societies 79: 800-811.

Moutinho, F. H. M., G. A. Marafão, M. do Carmo Calijuri, M. Z. Moreira, A. M. Marcarelli \& D. G. F. Cunha, 2021. Environmental factors and thresholds for nitrogen fixation by phytoplankton in tropical reservoirs. Internattional Review Hydrobiolology 106: 5-17.

Oh, H.-M., S. J. Lee, J.-H. Kim, H.-S. Kim \& B.-D. Yoon, 2001. Seasonal variation and indirect monitoring of microcystin concentrations in Daechung Reservoir, Korea. Applied Environmental Microbiology 67: 1484-1489.

Orihel, D. M., D. F. Bird, M. Brylinsky, H. Chen, D. B. Donald, D. Y. Huang, A. Giani, D. Kinniburgh, H. Kling, B. G. Kotak, P. R. Leavitt, C. C. Nielsen, S. Reddyk, R. C. Rooney, S. B. Watson, R. W. Zurawell \& R. D. Vinebrooke, 2012. High microcystin concentrations occur only at low nitrogen-to-phosphorus ratios in Canadian Lakes. Canadian Journal of Fisheries and Aquatic Sciences 69: 1457-1462.

Paerl, H. W., and J. Huisman, 2008. Blooms like it hot. Science 320: 57-58.

Paerl, H. W., J. T. Scott, M. J. McCarthy, S. E. Newell, W. S. Gardner, K. E. Havens, D. K. Hoffman, S. W. Wilhelm \& W. A. Wurtsbaugh, 2016. It takes two to tango: When and where dual nutrient $(\mathrm{N} \& \mathrm{P})$ reductions are needed to protect lakes and downstream ecosystems. Environmental Science and Technology 50: 10805-10813.

Raimbault, P., W. Pouvesta, F. Diaz, N. Garcia \& R. Sempéré, 1999. Wet-oxidation and automated colorimetry for simultaneous determination of organic carbon, nitrogen \& phosphorus dissolved in seawater. Marine Chemistry 66: 166-169.

Ratmaya, W., D. Soudant, J. Salmon-Monviola, M. Plus, N. Cochennec-Laureau, E. Goubert, F. Andrieux-Loyer, L. Barillé \& P. Souchu, 2019. Reduced phosphorus loads from the Loire and Vilaine rivers were accompanied by increasing eutrophication in the Vilaine Bay (south Brittany, France). Biogeosciences 16: 1361-1380 .

Ren, L., N. N. Rabalais, R. E. Turner, W. Morrison \& W. Mendenhall, 2009. Nutrient limitation on phytoplankton growth in upper Barataria Basin, Louisiana: Microcosm bioassays. Estuaries and Coasts 32: 958-974.

Ren, L., N. N. Rabalais \& R. E. Turner, 2020. Effects of Mississippi River water on phytoplankton growth and composition in the upper Barataria estuary, Louisiana. Hydrobiologia 847: 1831-1850.

Rinta-Kanto, J. M., E. A. Konopko, J. M. DeBruyn, R. A. Bourbonniere, G. L. Boyer \& W. Wilhelm, 2009. Lake Erie Microcystis: Relationship between microcystin production, dynamics of genotypes and environmental parameters in a large lake. Harmful Algae 8: 665-673.
Schindler, D. W., 2012. The dilemma of controlling cultural eutrophication of lakes. Proceedings of the Royal Society Section B-biological sciences 279: 4322-4333.

Schindler, D. W., S. R. Carpenter, S. C. Chapra, R. E. Hecky \& D. M. Orihel, 2016. Reducing phosphorus to curb lake eutrophication is a success. Environmental Sciences and Technology 50: 8923-8929.

Smith, V. H., 2003. Eutrophication of freshwater and coastal marine ecosystems. A global problem. Environmental Science and Pollution Research 10: 126-139.

Sterner, R. W., 2008. On the phosphorus limitation paradigm for lakes. International Review of Hydrobiology 93: 433-445.

Stow, C. A., R. D. DeLaune \& W. H. Patrick, Jr., 1985. Nutrient fluxes in a eutrophic coastal Louisiana freshwater lake. Environmental Management 9: 243-352.

Sundareshwar, P.V., Morris, J.T., 1999. Phosphorous limitation of coastal ecosystem processes. Science, 299: 563-565.

Taranu, Z. E., I. Gregory-Eaves, P. R. Leavitt, L. Bunting, T. Buchaca, J. Catalan, I. Domaizon, P. Guilizzoni, A. Lami, S. McGowan, H. Moorhouse, G. Morabito, F. R. Pick, M. A. Stevenson, P. L. Thompson \& R. D. Vinebrooke, 2015. Acceleration of cyanobacterial dominance in north temperate subarctic lakes during the Anthropocene. Ecology Letters 18: 375-384.

Turner, R. E., E. M. Swenson, C. Milan \& J. M. Lee, 2019. Spatial variations in Chlorophyll $a, \mathrm{C}, \mathrm{N}$, and $\mathrm{P}$ in a Louisiana estuary from 1994 to 2016. Hydrobiologia 834(1): 131-144.

Vanni, J. J., W. H. Renwick, A. M. Bowling, M. J. Horgan \& A.D. Christian, 2011. Nutrient stoichiometry of linked catchment-lake systems along a gradient of land use. Freshwater Biology 56: 791-811.

Ward, M. H., R. R. Jones, J. D. Brender, T. M. de Kok, P. J. Weyer, B. T. Nolan, C. M. Villanueva \& S. G. van Breda, 2018. Drinking water nitrate and human health: an updated review. International Journal Environmental Research and Public Health 15: 1557.

WHO (World Health Organization), 2020. Cyanobacterial toxins: microcystins: Background document for development of WHO Guidelines for drinking-water quality and Guidelines for safe recreational water environments. WHO/HEP/ECH/WSH/2020.6, World Health Organization, Geneva. Available at: https://apps.who.int/iris/ handle/10665/338066.

Wurtsbaugh, W. A., H. W. Paerl \& W. K. Dodds, 2019. Nutrients, eutrophication and harmful algal blooms along the freshwater to marine continuum. WIREs Water 6: e1373.

Publisher's Note Springer Nature remains neutral with regard to jurisdictional claims in published maps and institutional affiliations. 